\title{
Failure of thiazide diuretics to increase plasma calcium in mild primary hyperparathyroidism
}

\author{
C.W. Farquhar ${ }^{1}$, G.S. Spathis ${ }^{2}$, J.L. Barron ${ }^{3}$ and G.E. Levin ${ }^{1}$ \\ ${ }^{1}$ Department of Chemical Pathology, St. George's Hospital, London, Departments of ${ }^{2}$ Medicine and \\ ${ }^{3}$ Chemical Pathology, St. Helier Hospital, Carshalton, Surrey, UK.
}

\begin{abstract}
Summary: Thirteen patients with mild primary hyperparathyroidism who were taking thiazide diuretics intermittently for periods of up to 18 months were followed up for a mean of 5.3 years. No significant difference was found in either plasma total calcium corrected for albumin or whole blood ionized calcium in these patients between the periods on or of thiazides.

We conclude that thiazide diuretics are not contraindicated in such patients.
\end{abstract}

\section{Introduction}

Hypertension is recognized as a complication of primary hyperparathyroidism. Thiazides are widely used as antihypertensive agents but these diuretics have been claimed to exacerbate hypercalcaemia in this condition. ${ }^{1,2}$

Much of the evidence for a hypercalcaemic effect of thiazides in primary hyperparathyroidism comes from short term studies. Transient increases in total plasma calcium are well documented but there is conflicting evidence of change in ultrafiltrable or ionized calcium..$^{3-6}$ In the absence of longer term studies of the effect of thiazides we investigated plasma calcium concentrations in patients with mild primary hyperparathyroidism who had been receiving thiazides for up to 18 months.

\section{Patients and methods}

A retrospective study was performed on 13 patients who were being managed conservatively for mild asymptomatic primary hyperparathyroidism. The diagnosis was made by demonstrating hypercalcaemia (total calcium corrected for albumin $>2.60$ $\mathrm{mmol} / \mathrm{l}$, or ionized calcium $>1.28 \mathrm{mmol} / \mathrm{l}$ ) at the time of presentation and subsequently which was associated with inappropriately elevated plasma parathyroid hormone concentration. Nine female and four male subjects (mean age 53.9 years, range 36-71 years) were followed up for a mean of 5.3 years (range 1.5-10.7). All patients had received thiazides intermittently, and the corrected total

Correspondence: C.W. Farquhar, M.R.C.Path., Department of Chemical Pathology, St. George's Hospital, Blackshaw Road, London SW17 0QT, UK.

Accepted: 25 April 1990 calcium and ionized calcium concentration were compared when they had been receiving the drug for a minimum of one month, and when they had ceased taking the drug for at least three months. These periods were chosen to avoid any transient increases in plasma calcium concentrations due to thiazide therapy.

The thiazides administered to these patients were: polythiazide $1 \mathrm{mg} /$ day, cyclopenthiazide $500 \mu \mathrm{g} /$ day, chlorthalidone $25 \mathrm{mg} / \mathrm{day}$, bendrofluazide 2.5 or $5 \mathrm{mg} /$ day and Moduretic, which contains $50 \mathrm{mg}$ hydrochlorothiazide (and amiloride $5 \mathrm{mg}$ ), once daily.

Plasma total calcium and albumin were measured by standard methodology on a Technicon SMA $12 / 60$ analyser. Ionized calcium was measured in anaerobically-collected whole blood using a Radiometer ICA-1 ionized calcium electrode (Radiometer A/S, Copenhagen). The corrected calcium concentration was obtained using a laboratory derived correction factor derived from the linear regression of calcium against albumin in $\mathbf{3 0 0}$ normocalcaemic subjects.

Parathyroid hormone (PTH) was measured using an $\mathrm{N}$-terminal radioimmunoassay by the Supraregional Assay Service. The lower limit of detection of the assay was $40 \mathrm{pmol} / \mathrm{l}$.

\section{Results}

All 13 patients were shown to have primary hyperparathyroidism in that they had inappropriately elevated $(9 / 13)$ or detectable $(4 / 12)$ levels of PTH in the presence of hypercalcaemia (Table I). Although patient 5 did not have detectable PTH at presentation, he was later shown to have detectable PTH by an N-terminal radioimmunoassay at St. 
Table I Diagnostic criteria for primary hyperparathyroidism

\begin{tabular}{cccccc}
\hline $\begin{array}{l}\text { Patient } \\
\text { no. }\end{array}$ & Sex & $\begin{array}{c}\text { Age at } \\
\text { diagnosis } \\
\text { (years) }\end{array}$ & $\begin{array}{c}\text { Plasma total } \\
\text { Ca corrected } \\
\text { for albumin }\end{array}$ & $\begin{array}{c}\text { Whole blood } \\
\text { ionized Ca } \\
\text { (mmol/l) }\end{array}$ & $\begin{array}{c}\text { N-terminal } \\
\text { PTH }(\text { pmol/l) }\end{array}$ \\
\hline 1 & F & 42 & 2.74 & 1.49 & 82 \\
2 & F & 54 & 2.58 & 1.34 & 650 \\
3 & F & 36 & 2.82 & 1.44 & 180 \\
4 & F & 50 & 2.73 & 1.36 & 145 \\
5 & M & 60 & 2.95 & 1.43 & $<40$ \\
6 & F & 59 & 2.79 & 1.40 & 175 \\
7 & M & 63 & 2.65 & 1.30 & 110 \\
8 & M & 55 & 2.74 & N/A & 370 \\
9 & F & 71 & 2.94 & 1.57 & 230 \\
10 & F & 61 & 2.92 & 1.44 & $>2000$ \\
11 & F & 45 & 2.99 & 1.49 & 500 \\
12 & M & 60 & 2.66 & 1.39 & 140 \\
13 & F & 45 & 2.61 & 1.38 & 115 \\
\hline
\end{tabular}

Laboratory reference ranges: total calcium $2.20-2.60 \mathrm{mmol} / \mathrm{l}$; ionized calcium 1.20 $1.28 \mathrm{mmol} / \mathrm{l} ; \mathrm{N}$-terminal PTH up to $120 \mathrm{pmol} / \mathrm{l}$.

George's Hospital when this assay became available.

There were 23 episodes in which a patient had a period on thiazides followed by a period off thiazides or vice versa (Table II). The average duration of thiazide therapy was 6.5 months (Range 1-27 months). There was no significant difference in corrected total calcium when comparing patients on or off thiazides. In 14 of these paired episodes ionized calcium measurements were made, and similarly showed no significant difference.

\section{Discussion}

The results of this study do not provide evidence that patients with mild primary hyperparathyroidism are at risk from exacerbating pre-existing hypercalcaemia when taking thiazide diuretics.

The effect of thiazide diuretics upon calcium metabolism has been widely studied. Their main action is to reduce the urinary excretion of calcium, predominantly by increasing renal tubular reabsorption. Thiazides have been reported to cause hypercalcaemia in chronic renal failure, when urinary calcium excretion is already minimal, suggesting that bone resorption may play a role. ${ }^{7}$ In patients with normal calcium homeostasis, it is very uncommon for thiazides to induce hypercalcaemia ${ }^{8}$ as increased plasma calcium concentration suppresses parathyroid hormone secretion. However, patients with primary hyperparathyroidism show no decrease in parathyroid hormone excretion when given thiazides. ${ }^{9}$

Normal subjects who were studied for up to 2 weeks after a 4-week course of the diuretic, had significantly increased total and ionized calcium values while immunoreactive parathyroid hormone remained normal. ${ }^{8}$ By contrast, increases in plasma calcium (corrected for protein) were not found in healthy subjects after 4 days on thiazides, although significant increases were observed in patients with hyperparathyroidism. ${ }^{3}$ Jorgensen et al., however, were unable to demonstrate any change in ultrafiltrable or ionized calcium after 5

Table II Effect of thiazide diuretics on corrected total and ionized calcium in mild primary hyperparathyroidism

\begin{tabular}{|c|c|c|c|c|}
\hline & $\begin{array}{l}\text { Corrected } \\
\text { Off thiazides }\end{array}$ & $\begin{array}{l}d \text { calcium } \\
\text { On thiazides }\end{array}$ & $\begin{array}{r}\text { Ionized } \\
\text { Off thiazides }\end{array}$ & $\begin{array}{l}\text { calcium } \\
\text { On thiazides }\end{array}$ \\
\hline $\begin{array}{l}\text { No. of episodes } \\
\text { Mean }(\mathrm{mmol} / \mathrm{l}) \\
\text { Range* }(\mathrm{mmol} / \mathrm{l}) \\
\text { SEM }(\mathrm{mmol} / \mathrm{l})\end{array}$ & $\begin{array}{c}23 \\
2.615 \\
2.31-3.16 \\
0.037\end{array}$ & $\begin{array}{c}23 \\
2.624 \\
2.34-3.06 \\
0.036\end{array}$ & $\begin{array}{c}14 \\
1.436 \\
1.29-1.68 \\
0.031\end{array}$ & $\begin{array}{c}14 \\
1.428 \\
1.27-1.57 \\
0.025\end{array}$ \\
\hline Paired $t$ test & \multicolumn{2}{|c|}{ NS } & \multicolumn{2}{|c|}{ NS } \\
\hline
\end{tabular}

*Min-max values; NS = not significant. 
days of hydrochlorothiazide in 10 hyperparathyroid patients. ${ }^{4}$

We were unable to find reports of the effect of long term thiazide administration in primary hyperparathyroidism. Klimiuk et al. reported on 6 hypercalcaemic patients receiving thiazides who were subsequently found to have primary hyperparathyroidism. Withdrawal of the diuretic for 6 days led to a small but significant fall in total serum

\section{References}

1. Yendt, E.R. \& Cohanim, M. Prevention of calcium stones with thiazides. Kidney Int 1978, 13: 397-409.

2. Aurbach, G.D., Marx, S.J. \& Spiegel, A.M. Parathyroid hormone, calcitonin and the calciferols. In: Wilson, J.D. \& Foster, D.W. (eds) Williams Textbook of Endocrinology 1985, p. 1198.

3. Brickman, A.S., Massry, S.G. \& Coburn, J.W. Changes in serum and urinary calcium during treatment with hydrochlorothiazide: Studies on mechanisms. J Clin Invest 1972, 51: 945-954.

4. Jorgensen, F.S., Transbol, I. \& Binder, C. The effect of bendroflumethiazide on total, ultrafiltrable and ionised calcium in serum in normocalcaemic renal stone formers and in hyperparathyroidism. Acta Med Scand 1973, 194: 323-326.

5. Adams, P., Chalmers, T.M., Hill, L.F. \& Truscott, B.M Idiopathic hypercalciuria and hyperparathyroidism. Br Med J 1970, 2: 582-585. calcium. ${ }^{9}$ The significance of this finding is limited by the brief duration of the study.

It is concluded that despite assertions to the contrary ${ }^{1,2}$ the prolonged use of thiazides in mild primary hyperparathyroidism does not lead to a significant increase in plasma calcium or whole blood ionized calcium concentration. It is our view that these drugs need not necessarily be withheld in this group of patients.

6. Parfitt, A.M. Chlorothiazide induced hypercalcaemia in juvenile osteoporosis and hyperparathyroidism. $N$ Engl $\mathrm{J}$ Med 1969, 281: 55-59.

7. Koppel, M.H., Massry, S.G., Shinaberger, J.H., Hartenbower, D.L. \& Coburn, J.W. Thiazide-induced rise in serum calcium and magnesium in patients on maintenance hemodialysis. Ann Int Med 1970, 72: 895-901.

8. Stote, R.M., Smith, L.H., Wilson, D.M., Dube, W.J., Goldsmith, R.A. \& Arnaud, C.D. Hydrochlorothiazide effects on serum calcium and immunoreactive parathyroid hormone concentrations. Ann Int Med 1972, 77: 587-591.

9. Klimiuk, P.S., Davies, M. \& Adams, P.H. Primary hyperparathyroidism and thiazide diuretics. Postgrad Med J 1981 , 57: $80-83$. 